\title{
Immunocompetent patient with cerebral cryptococcosis: case report
}

\author{
Luis Cuitláhuac Becerra-Pedraza1, Daniel Arturo Martínez-Piña², Génesis Rocío Calles-Carmona ${ }^{3}$ and \\ Daniel San-Juan ${ }^{4}$ \\ ${ }^{1}$ Stroke Clinic; '2Department of Neurophysiology, Instituto Nacional de Neurología y Neurocirugía Manuel Velasco Suárez, Ciudad de México; \\ ${ }^{3}$ Department of Teaching, Hospital Psiquiátrico de Tampico, Tampico, Tamps.; ${ }^{4}$ Department of Clinical Research, Instituto Nacional de Neurología \\ y Neurocirugía Manuel Velasco Suárez, Ciudad de México, Mexico
}

\begin{abstract}
A 14-year-old female, presenting sudden and progressive holocraneal headache along with incoercible vomiting arrived to emergency room. Acute confusional state and meningoencephalitis syndrome where identified. Brain computed tomography-scan with normal results was performed. Lumbar puncture with crystal-clear cerebrospinal fluid was obtained: low glucose, elevated proteins and cell-count of 15/mm. China-Ink and Criptococcus neoformans culture both positive. Viral, lupus-anticoagulant, and HIV tests negative. Fluconazole $200 \mathrm{mg} / \mathrm{kg} /$ day, amphotericin-B $0.7 \mathrm{mg} / \mathrm{kg} /$ day, dexamethasone $1 \mathrm{mg} / \mathrm{kg} /$ day were prescribed. 48-h later evolved to cerebral edema, multiple-organ-failure and death. Hereby we present a Cryptococcus spp. infection case report, addressing the public health challenge and vulnerability of immunocompromised patients in Mexico.
\end{abstract}

KEY WORDS: Headache. Cerebral cryptococcosis. Cryptococcus gattii. Cryptococcus neoformans. Multiple organ failure. Immunocompetent. Meningoencefalic syndrome.

\section{Introduction}

Cryptococcosis is an opportunistic fungal disease caused by a globally-distributed yeast-like, encapsulated fungus ${ }^{1}$. There are two pathogenic varieties in the human being: Cryptococcus neoformans var. neoformans, which causes the majority of infections in immunocompromised patients, and var. gatti, which affects immunocompetent individuals and exists in both tropical and subtropical areas ${ }^{2-4}$.

Cryptococcosis diagnosis is based on a detailed patient history, since symptoms depend on the area compromised in the central nervous system (CNS). In case of clinical suspicion after cytological, cytochemical and cerebrospinal fluid (CSF) staining tests, an enzyme-linked immunosorbent assay (ELISA) or a latex agglutination test should be carried out; when both these are negative, the CSF culture results should be awaited ${ }^{5}$. Untreated meningitis by Cryptococcus spp. is fatal, while $60-70 \%$ of patients without AIDS who are treated have good prognosis ${ }^{6,7}$.

The present case exemplifies the importance of Cryptococcus spp. infection in immunocompetent patients in our country, since in spite of medical management and standardized treatment, the patient had organ dysfunction and died.

\section{Case presentation}

This is the case of a 14-year-old female patient, resident of an urban area in Morelia, Michoacán, who had a low socioeconomic status and poor hygienic-dietary habits. She had complied with her vaccination schedule. She had no relevant personal, family or

\author{
Correspondence: \\ Luis Cuitláhuac Becerra-Pedraza \\ Avda. Insurgentes Sur, 3877 \\ Col. La Fama, Del. Tlalpan \\ C.P. 14269, Ciudad de México, México \\ E-mail: Ic_bec@outlook.com
}

Date of reception: 17-07-2016

Date of acceptance: 18-08-2016

DOI://dx.doi.org/10.24875/GMM.M18000097
Gac Med Mex. 2017;153:829-832

Contents available at PubMed www.gacetamedicademexico.com 
psychiatric history. Her condition had started in December 2014 with holocranial headache of sudden and progressive onset, which was oppressive, constant, with no rhythm or irradiation, 8/10 intensity in the verbal rating scale for pain (VRSP), and was unsuccessfully treated with acetaminophen, with onemonth evolution.

At her admission to the emergency department on January 2014, the patient presented with constant holocranial headache of VRSP 9/10 in intensity, accompanied by nausea, vomiting and tonic-clonic seizures. Her vital signs were: heart rate, 110 beats per minute; respiratory rate, 25 breaths per minute, blood pressure, $100 / 75 \mathrm{mmHg}$, moderate dehydration, acute confusional syndrome with psychomotor agitation state and meningoencephalic syndrome. Laboratory tests at admission showed blood count with leukocytosis and normal blood chemistry and coagulation times; normal plain and contrast cranial computed tomography (CT) (Fig. 1). Empirical treatment was started with ceftriaxone, $1 \mathrm{~g}$ every $12 \mathrm{~h}$ by intravenous (IV) route, and vancomycin, $15 \mathrm{mg} / \mathrm{kg}$ IV every $12 \mathrm{~h}$. Lumbar puncture for CSF showed $80 \mathrm{mmH}^{2} \mathrm{O}$ opening pressure; cytochemistry: xantochromic color; transparent appearance; protein, $78 \mathrm{mg} / \mathrm{dL}$; glucose, $14 \mathrm{mg} / \mathrm{dL}$; cellularity, $15 / \mathrm{mm}$; lymphocytes, $20 \%$; polymorphonuclear cells, $76 \%$ and monocytes, $4 \%$. Cryptococcus neoformans was observed with India ink (Fig. 2). Therefore, treatment was started at $48 \mathrm{~h}$ with fluconazole $200 \mathrm{mg} / \mathrm{kg} /$ day, amphotericin B $0.7 \mathrm{mg} / \mathrm{kg} /$ day and dexamethasone $2 \mathrm{mg} / \mathrm{kg} /$ day. The TORCH, VDRL, B19 parvovirus, Epstein-Barr virus, anti-dsDNA (256 IU/mL), ANA (1:40) and HIV tests were negative. The CSF culture showed development of $C$. neoformans (sensitive to flucytosine $\leq 1$ minimum inhibitory concentration [MIC] amphotericin $\mathrm{B}=$ $1 \mathrm{MIC}$ and fluconazole $=2 \mathrm{MIC}$ ).

In spite of the treatment, the patient evolved with severe cerebral edema and neurological deterioration (Fig. 3), she developed multiple organ failure and died 3 days later. No autopsy was practiced.

\section{Discussion}

Cerebral cryptococcosis in immunocompetent patients is rare, and only a few have been reported in the world cases ${ }^{8}$. The variety of Cryptococcus is determinant for infection in immunocompetent patients but, unfortunately, in most cases the variety is not known, since the performance of polymerase chain reaction and ELISA is not common practice. Currently,

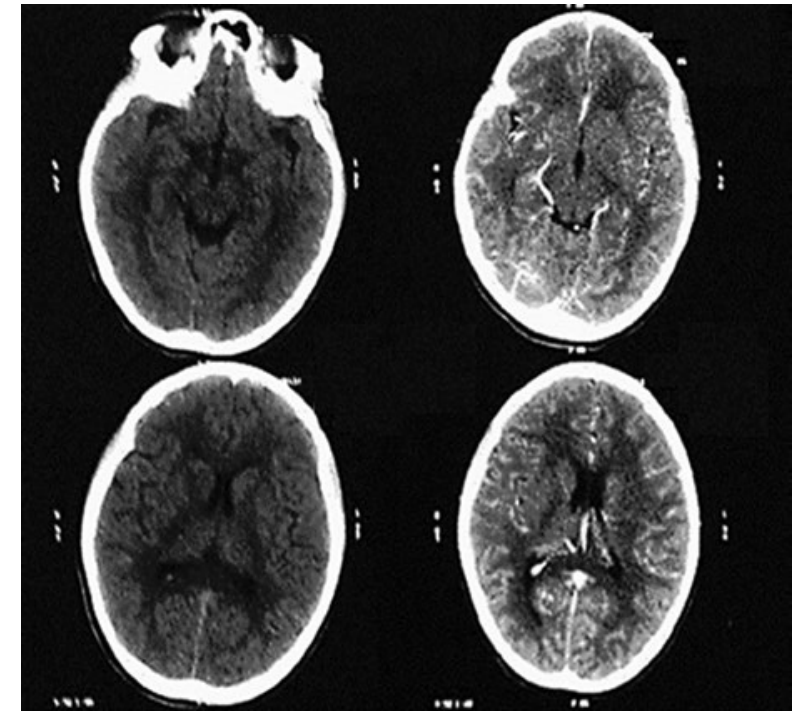

Figure 1. Normal plain cranial tomography at emergency department admission.
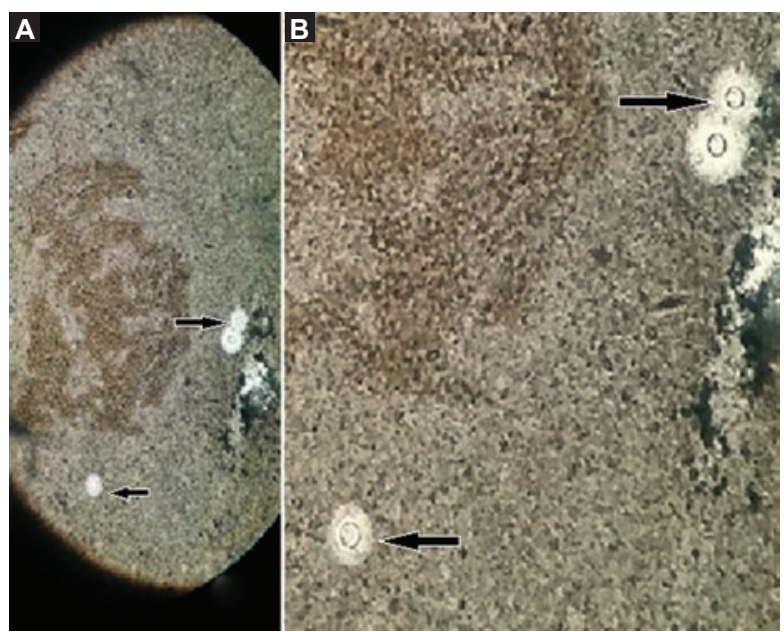

Figure 2. Bacterioscopic examination with India ink, where Cryptococcus neoformans are observed (arrows). A: 10x. B: 40x.

chronic undernourishment is an important element in developing countries ${ }^{9}$; coexistence with poultry and pigeons is the most common risk factor. The risk factors identified in our patient were being resident of a marginalized urban area and coexistence with poultry. In Mexico, C. neoformans has been isolated in $20.7 \%$ of pigeon excrements collected in urban areas, and to a lesser proportion in vegetables, fruits and other birds' excrements ${ }^{10}$.

Most common clinical presentation is pulmonary, wherefrom it can spread by the hematogenous route to the CNS and cause meningoencephalitis ${ }^{11-13}$. When travelling through the blood stream, the fungus inhibits the host's immune response and the production of tumor necrosis factor, among others ${ }^{14,15}$. Our patient had no data consistent with prior pulmonary infection; 


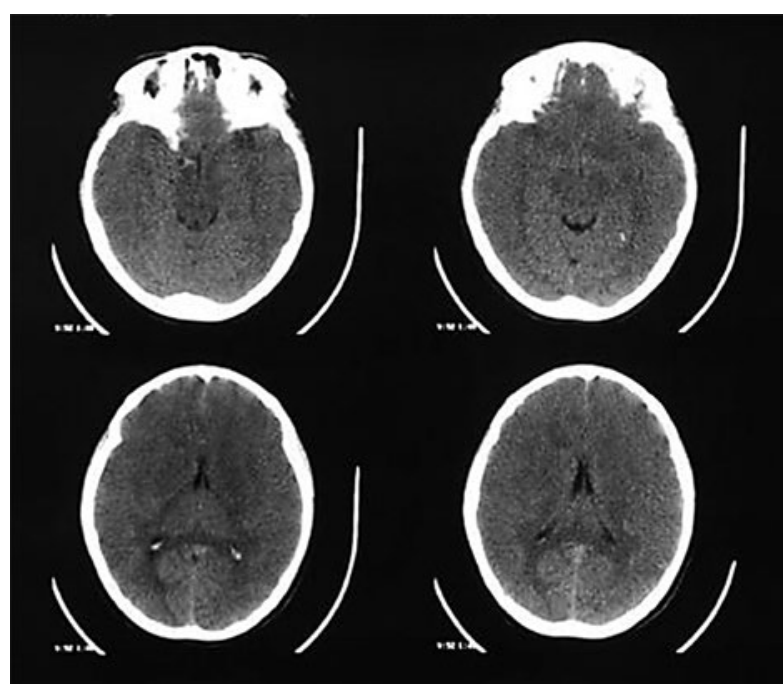

Figure 3. Plain cranial tomography showing severe cerebral edema.

cases of asymptomatic pulmonary cryptococcosis and pulmonary infection-secondary meningoencephalitis have been reported without pulmonary clinical or radiologic data and, in these cases, the pulmonary infection is controlled by granulomas that disappear after weeks or months ${ }^{16,17}$. Cryptococcosis presentation in the CNS can be as cysts in the cerebral cortex with granulomatous meningeal reaction, or granulomas in the white matter known as cryptococcomas ${ }^{18,19}$, which were not detected in our patient; her medical condition precluded the performance of magnetic resonance.

Cryptococcosis clinical manifestations appear at 1 to 2 weeks after exposure to spores in bird feces, plants (eucalypts) and animals (e,g., koalas) ${ }^{20}$. Immunocompetent patients can develop symptoms after months or with slow progression. Initial symptoms include progressive holocranial headache, general deterioration and fever that only occurs in $50 \%$ of cases. As for neurological symptoms, higher prevalence and more intensity have been observed in immunocompetent patients, with local or general manifestations depending on the area affected by the yeasts ${ }^{21-23}$. In our patient, the first CT was normal; however, it has been documented that CT can be normal or show cryptococcomas in $38-58 \%$, cerebral edema, hydrocephaly or meningeal enhancement. Magnetic resonance is more sensitive to detect nodules within the cerebral parenchyma; meninges, basal ganglia and mesencephalon are abnormal in $40 \%$ of patients with the infection typical presentation ${ }^{23,24}$. CSF cytochemical examination shows lymphocytic pleocytosis, hyperproteinorachia and hypoglycorrhachia, and the Indian ink test is positive in $50 \%$ of patients without IIDS $^{25}$. The most widely used diagnostic method is Cryptococcus culture $(90 \%$ sensitivity); however, latex agglutination has been reported to be the diagnostic test with the highest sensitivity and specificity with titers higher than $1: 2048^{26}$.

Regardless of patient neurological and immune status, the recommended treatment for cerebral cryptococcosis is with amphotericin B $(0.7-1.0 \mathrm{mg} / \mathrm{kg}$ per day IV) plus flucytosine $(100 \mathrm{mg} / \mathrm{kg}$ per day by oral route, in four divided doses) for at least 4 weeks, and when there are complications (intracranial hypertension, among others), 6 weeks of induction therapy are recommended to subsequently start consolidation with fluconazole $(400 \mathrm{mg} /$ day) for 8 weeks. After induction and consolidation therapy, maintenance therapy is established with fluconazole, at $200 \mathrm{mg}$ per day for 6-12 months ${ }^{27}$.

Prognosis is poor in immunodepressed and immunocompetent patients without treatment; with treatment, worldwide-reported mortality in immunocompetent patients is $27 \%$, and in immunodepressed subjects it is $32 \%{ }^{28,29}$. Cerebral cryptococcosis in immunocompetent patients is infrequent; however, it can have a fatal evolution in spite of currently recommended antimicrobial treatment.

\section{Acknowledgements}

We thank the Armstrong Foundation for having awarded Daniel Arturo Martínez Piña and Luis Cuitláhuac Becerra Pedraza with the undergraduate grant for the January-June 2016 period at the National Institute of Neurology and Neurosurgery.

\section{References}

1. Padilla $M C$, Navarrete $G$, Pérez $S$, et al. Criptococcosis diseminada asociada con VIH. Dermatol Rev Mex. 2012;56:126-31.

2. Tello M, Gutiérrez E, Béjar V, et al. Criptococosis. Rev Med Risaralda. 2013;19:147-53.

3. Azuero LF, Quintero P, Mayor L, et al. Meningitis en paciente VIH negativo. Rev Cienc Salud/Bogotá (Colombia). 2006;4:75-8.

4. García JL, Novoa AM. Criptococcosis. Una amenaza para pacientes inmunodeprimidos. Gaceta Médica Espirituana. 2011;13(3).

5. Gaona VA. Central nervous system and Cryptococcus neoformans. N Am J Med Sci. 2013;5:492-3.

6. Roebuck DJ, Fisher DA, Curie BJ. Cryptococosis in VIH negative patients: findings on chest radiography. Thorax. 1998;53:554-7.

7. Vázquez $\mathrm{O}$, Martínez BI, Campos RT. Criptococosis. Historia natural y estado actual del tratamiento. Acta Pediatr Mex. 2005;26:18-28.

8. Lee SJ, Choi HK, Son J, et al. Cryptococcal meningitis in patients with or without human immunodeficiency virus: experience in a tertiary hospital. Yonsei Med J. 2011;52:482-7.

9. Mitchell TG, Perfect JR. Cryptococcosis in the era of AIDS - 100 years after the discovery of Cryptococcus neoformans. Clin Microbiol Rev. 1995;8:515-48.

10. Galnares JA, Loza S, Gómez F, et al. Criptococosis meníngea en un paciente inmunocompetente: reporte de un caso y revisión de la literatura. Revista Médica del Hospital General de México. 2014;77(3). 
11. May RC, Stone NR, Wiesner DL, et al. Cryptococcus: from environmental saprophyte to global phatogen. Nature Reviews Microbiology. 2016;14:106-17.

12. Chang CC, Sorrell TC, Chen SC. Pulmonary cryptococcosis. Semin Respir Crit Care Med. 2015;36:681-91.

13. Gullo FP, Rossi SA, Sardi J, et al. Cryptococcosis: epidemiology, fungal resistance, and new alternatives for treatment. Eur J Clin Microbiol Infect Dis. 2013;32:1377-91

14. Huston SM, Li SS, Stack D, et al. Cryptococcus gatti is killed by dendritic cells, but evades adaptive immunity by failing to induce dendritic cell maturation. J Immunol. 2013;191:249-61.

15. Price MS, Perfect JR. Host defenses against cryptococcosis. Immunol Invest. 2011;40:786-808.

16. Yang $\mathrm{CJ}$, Hwang JJ, Wang $\mathrm{TH}$, et al. Clinical and radiographic presentations of pulmonary cryptococcosis in immunocompetent patients. Scand J Infect Dis. 2006;38:788-93.

17. Ganiem AR, Indrati AR, Wisaksana R, et al. Asymptomatic cryptococcal antigenemia is associated with mortality among HIV-positive patients in Indonesia. J Int AIDS Soc. 2014;17:188-21.

18. Pyrgos V, Seitz A, Steiner C, et al. Epidemiology of Cryptococcal meningitis in the US: 1997-2009. Plos One. 2013;8:1-6.

19. Díaz JA, García JA, Mantilla JC et al. Criptococoma en el sistema nervioso central de un paciente no inmunoafectado. Rev Neurol. 2008;46:97-101.

20. Agüero B, Garza D, Flores V, et al. Aislamiento y caracterización de Cryptococcus neoformans var. gattii a partir de muestras de Eucalyptus camaldulensis en la ciudad de México. Rev Iberoam Micol. 1999;16:40-2.
21. Lui G, Lee N, Ip M, et al. Cryptococcosis in apparently immunocompetent patients. QJM. 2006;99:143-51.

22. Galnares J, Loza S, Gómez F, et al. Criptococosis meníngea en un paciente inmunocompetente: reporte de un caso y revisión de la literatura. Rev Med Hosp Gen Mex. 2014;77:109-13.

23. Lui G, Lee N, Ip M, et al. Cryptococcosis in apparently immunocompetent patients. QJ Med. 2006;99:143-51.

24. Hoang L, Philips P, Galanis E. Cryptococcus gatti: a review of the epidemiology, clinical presentation, diagnosis, and management of this endemic yeast in the Pacific Northwest. Clin Microbiol Newsletter. 2011;33:187-95.

25. Loyse A, Moodley A, Rich P, et al. Neurological, visual, and MRI brain scan findings in 87 South African patients with HIV-associated cryptococcal meningoencephalitis. J Infect. 2015;70:668-75.

26. Gómez B, Zarco L. Criptococosis meníngea: características clínicas y de laboratorio. Acta Neurol Colomb. 2011;27:9-27.

27. Mukhopadhyay S. Role of histology in the diagnosis of infectious causes of granulomatous lung disease. Curr Opin Pulm Med. 2011;17:189-96.

28. Perfect J, Dismukes W, Dromer F, et al. Clinical practice guidelines for the management of cryptococcal disease: 2010 update by the Infectious Diseases Society of America. Clin Infect Dis. 2010;50:291-322.

29. Lizarazo J, Chaves O, Peña $Y$, et al. Comparacion de los hallazgos clínicos y de supervivencia entre pacientes VIH positivos y VIH negativos con criptococosis meníngea en un hospital de tercer nivel. Acta Médica Colombiana. 2012;37(2). 